\title{
PENERAPAN STRATEGI PEMBELAJARAN ACTIVE LEARNING PADA MATERI EKOSISTEM UNTUK MENINGKATAN KEMANDIRIAN BELAJAR SISWA
}

\section{APPLICATION OF ACTIVE LEARNING STRATEGIES IN MATERIAL ECOSYSTEM TO INCREASE STUDENT LEARNING INDEPENDENCE}

\author{
Ruslaini $^{1}$, Trisnia Novika ${ }^{2}$ \\ 1,2 Universitas Iskandar Muda, Aceh, Indonesia. \\ ${ }^{1}$ Email: ruslaini@unida-aceh.ac.id \\ ${ }^{2}$ Email: nianovi16@gmail.com
}

\begin{abstract}
ABSTRAK
Kemandirian adalah suatu proses belajar setiap individu untuk mengambil inisiatif secara mandiri dalam mendiagnosa kebutuhan belajar, salah satu upaya melalui Penerapan Strategi Pembelajaran Active Learning dalam Pembelajaran IPA materi ekosistem. Penelitian ini bertujuan untuk memperoleh cara-cara meningkatkan kemandirian belajar siswa Kelas V SD Negeri Kandang. Jenis penelitian ini adalah kuantitatif. Populasinya seluruh siswa kelas V yang berjumlah 16 orang, terdiri dari 11 perempuan dan 5 laki laki. Metode yang digunakan adalah metode statistika dengan menghitung presentase dari jawaban angket. Teknik pengumpulan data terdiri dari observasi, test dan angket. Hasil penelitian menunjukkan penerapan strategi pembelajaran Active Learning dapat meningkatkan Kemandirian belajar siswa Kelas V SD Negeri Kandang, hal ini ditunjukkan dari hasil evaluasi siswa dari pertemuan I dan II bahwa adanya perubahan nilai rata-rata yang didapatkan Pada Pre-test, 68,1 dan pada post-test yaitu 80,9. Maka Penerapan Strategi Pembelajaran Active Learning dapat meningkatkan hasil kemandirian belajar siswa kelas V SD Negeri Kandang.
\end{abstract}

Kata Kunci: Kemandirian, Aktive Learning, Ekosistem.

\begin{abstract}
Independence is a learning process for each individual to take the initiative independently in diagnosing learning needs, one of the efforts is through the Application of Active Learning Strategies in Natural Science Learning in ecosystem materials. This study aims to find ways to improve the learning independence of the fifth grade students of SD Negeri Kandang. This type of research is quantitative. The population was all students in grade $V$, amounting to 16 people, consisting of 11 girls and 5 boys. The method used is the statistical method by calculating the percentage of the questionnaire answers. The data collection technique consisted of observation, test and questionnaire. The results showed that the application of Active Learning learning strategies can improve the learning independence of Class $V$ students at SD Negeri Kandang, this is shown from the results of student evaluations from meetings I and II that there is a change in the average value obtained in the pre-test, 68.1 and in post-test is 80.9. So the application of Active Learning Learning Strategies can improve the results of the independent learning of grade V SD Negeri Kandang students.
\end{abstract}

Keywords: Independence, Active Learning, Ecosystem. 


\section{PENDAHULUAN}

Active learning strategy adalah sebuah kesatuan sumber kumpulan strategi-strategi pembelajaran yang komprehensif yang meliputi berbagai cara untuk membuat peserta didik menjadi aktif untuk mengoptimalkan penggunaan semua potensi yang dimiliki, sehingga semua anak didik dapat mencapai hasil belajar yang memuaskan sesuai dengan karakteristik pribadi yang mereka miliki. Disamping itu, pembelajaran aktif (active learning) juga dimaksudkan untuk menjaga perhatian siswa didik agar tetap tertuju pada proses pembelajaran. Pembelajaran aktif merupakan segala bentuk pembelajaran yang memungkinkan siswa berperan secara aktif dalam proses pembelajaran itu sendiri baik dalam bentuk interaksi sesama siswa maupun siswa dengan pengajar dalam proses pembelajaran tersebut (Agus N Cahyo, 2013: 137).

Hasil studi awal di SD Negeri Kandang kelas V pada materi ekosistem, peneliti mendapatkan informasi tentang kemandirian siswa yang masih sangat minim dalam proses belajar mengajar. Pembelajaran yang berlangsung guru cenderung menggunakan metode yang sifatnya konvensional, sehingga mengakibatkan anak didik kurang aktif dalam proses belajar mengajar, Hal ini terlihat ketika diberi pertanyaan oleh guru, siswa masih takut untuk menjawab. Ketika mengerjakan soal latihan yang seharusnya dikerjakan sendiri, siswa juga tidak yakin dengan jawabannya sendiri sehingga menyontek jawaban teman. Ketidakyakinan diri ini berdampak pada perilakunya, menyebabkan siswa kurang memahami materi yang dipaparkan oleh guru. Tentunya hal teresbut akan berdampak terhadap hasil belajar siswa yang umumnya tidak mencapai Kriteria Ketuntasan Minimal (KKM) yang telah ditetapkan.

Dalam pembelajaran IPA khususnya pada materi ekosistem guru bisa memanfaatkan lingkungan sekitar untuk memotivasi siswa supaya aktif dalam mengambil inisiatif secara mandiri. Kemandirian dalam belajar diartikan sebagai aktivitas belajar yang berlangsungnya lebih didorong oleh kemauan sendiri, pilihan sendiri, dan tanggung jawab sendiri dari pembelajar. kemandirian belajar yaitu proses ketika individu mengambil inisiatif sendiri, dengan atau tanpa bantuan orang lain, untuk mendiagnosis kebutuhan belajar, memformulasikan tujuan belajar sendiri, mengidentifikasi sumber belajar, memilih dan menentukan pendekatan strategi belajar, dan melakukan evaluasi hasil belajar yang dicapai. Haris Mudjiman (2008:7) menyebut kemandirian belajar dengan istilah belajar mandiri adalah kegiatan belajar aktif, yang didorong oleh niat atau motif untuk menguasai suatu kompetensi guna mengatasi suatu masalah, dan dibangun dengan bekal pengetahuan atau kompetensi yang telah 
dimiliki. Penetapan kompetensi sebagai tujuan belajar dan cara pencapaiannya dilakukan oleh pembelajar sendiri. Penetapan tersebut meliputi penetapan waktu belajar, tempat belajar, irama belajar, tempo belajar, cara belajar, sumber belajar, dan evaluasi hasil belajar.

Kemandirian belajar berasal dari dua kata yaitu kemandirian dan belajar. Kemandirian berasal dari kata-kata mandiri, dalam bahasa Jawa berarti berdiri sendiri (Hasan Basri, 2006:53). Desain induk pendidikan karakter Kementrian Pendidikan dan Kebudayaan juga menyebutkan mandiri sebagai salah satu karakter yang diharapkan dari pendidikan di Indonesia. Mandiri adalah sikap dan perilaku yang tidak mudah tergantung pada orang lain dalam menyelesaikan tugas-tugas (Pusat Kurikulum, 2010:10). Kemandirian anak sangat penting bagi perkembangan jiwa anak karena akan menimbulkan tingkat kepercayaan diri anak (Imam Musbikin, 2006: 50). Selanjutnya, Imam Musbikin mengungkapkan dampaknya adalah anak memiliki semangat melakukan aktivitasnya dan memiliki keinginan untuk banyak mencoba sesuatu yang baru dan meningkatkan prestasinya.

Dalam konteks belajar, kemandirian diperlukan sebagai bekal pendidikan sepanjang hayat. Pribadi yang tidak memiliki kemandirian belajar dapat mengalami kebiasaan yang kurang baik dalam melaksanakan pendidikan sepanjang hayat. Hal ini seperti dikemukakan Desmita (2012:189) bahwa dalam konteks belajar, terlihat adanya fenomena peserta didik yang kurang mandiri dalam belajar, yang dapat menimbulkan kebiasaan belajar yang kurang baik, seperti tidak betah belajar lama atau belajar hanya menjelang ujian, membolos, mencontek, dan mencari bocoran soal-soal ujian.

Mohammad Asrori

(2009:127)

menyebutkan gejala negatif yang tampak menjauhkan individu dari kemandirian antara lain:

1) Ketergantungan disiplin pada kontrol luar dan bukan karena niat sendiri yang ikhlas. Perilaku seperti ini akan mengarah kepada perilaku formalistik dan ritualistik serta tidak konsisten. Situasi seperti ini akan menghambat pembentukan etos kerja dan etos kehidupan yang mapan sebagai salah satu ciri dari kualitas sumber daya dan kemandirian manusia;

2) Sikap tidak peduli terhadap lingkungan hidup.

Peran guru sangat penting dalam menumbuhkan kemandirian belajar siswa dengan memberikan kebebasan menentukan pilihan atas inisiatif sendiri. Haris Mujiman (2011: 169) menyebutkan bahwa tugas guru dalam belajar mandiri yang dilakukan oleh siswa yaitu:

1) Mengajar dengan bahan dan cara yang merangsang siswa untuk tertarik memperdalam dan mengembangkannya sendiri; 
2) Memberikan bantuan kepada siswa dalam proses pendalaman dan pengembangan.

Guru harus mampu memberikan Rangsangan guna menumbuhkan kemauan belajar, hal ini juga dapat dilakukan dengan menciptakan kegiatan belajar aktif yang melibatkan siswa. Terdapat beberapa strategi belajar-mengajar dan kegiatan belajar-mengajar yang dapat memberi peluang pengembangan kemandirian dalam belajar. Keterampilan belajar mandiri yang perlu ditumbuhkan pada dirisiswa menurut Haris Mujiman (2011: 24) yaitu menetapkan tujuan belajar, menetapkan input belajar, dan menentukan proses belajar untuk mencapai tujuan. Selanjutnya, Haris Mujiman (2011: 100) juga menyebutkan bahwa untuk menumbuhkan kemauan belajar mandiri siswa, pengelolaan pembelajarannya harus dapat membuat siswa tertarik kepada materi belajar, dan berniat, serta mengambil langkah untuk memper dalamnya atas inisiatif sendiri. Ketika siswa diizinkan untuk menentukan pilihan belajar, mereka membangun rasa komitmen yang lebih kuat terhadap pembelajaran, rasa memiliki atas pekerjaan mereka, dan tingkat tanggung jawab yang lebih tinggi

\section{METODE PENELITIAN}

Jenis penelitian yang digunakan dalam penelitian ini adalah penelitian kuantitatif. Penelitian kuantitatif adalah suatu proses menemukan pengetahuan yang menggunakan data berupa angka sebagai alat menganalisis keterangan mengenai apa yang ingin diketahui. Sampel dalam penelitian ini seluruh siswa kelas V SD Negeri Kandang yang berjumlah 16 orang yang terdiri dari 11 perempuan dan 5 orang lakilaki. Teknik pengumpulan data dilakukan dengan menggunakan observasi, pre-test dan post-test serta angket

\section{TEKNIK ANALISIS DATA}

\section{Analisis Data Observasi}

Data hasil observasi kemandirian belajar siswa dianalisis menggunakan statistik deskriptif. Indikator jawaban Ya diberi skor 1 dan jawaban Tidak diberi skor 0. Hasil skor dijumlahkan kemudian dipersentasekan dengan cara membagi jumlah skor yang diperoleh dengan skor ideal kemudian dikalikan 100 persen (Nana Sudjana, 2005:133). Jika ditampilkan menjadi rumus, maka rumusnya adalah sebagai berikut:

$$
\text { Persentase }=\frac{\text { Skor yang diperoleh }}{\text { skor ideal }} \times 100 \%
$$

Angka-angka presentase yang diperoleh dari hasil perhitungan rumus tersebut penulis sajikan dalam tabel.

\section{Analisis Data Hasil Angket}

Data hasil angket dianalisis secara deskriptif kuantitatif. Indikator jawaban Ya diberi skor 1 dan jawaban Tidak diberi skor 0 . Hasil skor kemudian dijumlahkan. Selanjutnya, 
hasil skor dipersentasekan dengan cara membagi jumlah skor yang diperoleh dengan skor ideal kemudian dikalikan 100 persen. Jika ditampilkan menjadi rumus, maka rumusnya adalah sebagai berikut:

$$
\text { Persentase }=\frac{\text { Skor yang diperoleh }}{\text { skor } \text { ideal }}
$$

Angka-angka presentase yang diperoleh dari hasil perhitungan rumus tersebut penulis sajikan dalam tabel.

Setelah semua data observasi dan angket terkumpul, maka selanjutnya dilakukan analisa atau pengolahan data yang bertujuan untuk mengetahui Peningkatan Kemandirian Belajar Siswa Kelas V SD Negeri Kadang dalam Pembelajaran IPA melalui Penerapan Strategi Pembelajaran Active Learning. Data yang telah terkumpul kemudian diolah dan dianalisis dengan menggunakan metode statistik. Setelah data disusun dalam bentuk tabulasi, kemudian menghitung persentasi dari setiap jawaban tersebut. Selanjutnya data yang telah dimasukkan kedalam table distribusi frekwensi ditentukan prosentase perolehan $(\mathrm{P})$ untuk tiaptiap katagori dengan menggunakan rumus (Budiarto, 2012):

$\mathrm{P}=\frac{f}{n} x 100 \%$

\section{Keterangan:}

P : Persentase $\mathrm{n} \quad$ : Jumlah responden yang menjadi sampel

f : Frekuensi yang teramati

100 : nilai tetap

Pengolahan data dilakukan dengan cara mengumpulkan data pretest dan posttest. Data yang diperoleh dari hasil test selanjutnya dihitung untuk mencari rata-rata dengan menggunakan rumus sebagai berikut:

$\dot{\bar{X}}=\frac{\sum x}{N}$

Keterangan :

$\bar{X}=$ Rata-rata

$\sum X=$ Jumlah seluruh skor

$N=$ Jumlah individu

Setelah nilai rata-rata diperoleh, maka klasifikasi nilai dapat dilihat pata tabel 1 . berikut ini:

\begin{tabular}{|c|c|c|c|}
\hline No & $\begin{array}{c}\text { Kategori } \\
\text { Huruf }\end{array}$ & Kategori & $\begin{array}{c}\text { Bentuk } \\
\text { Nilai }\end{array}$ \\
\hline 1 & A & $\begin{array}{c}\text { Sangat } \\
\text { Baik }\end{array}$ & $80-100$ \\
\hline 2. & B & Baik & $70-79$ \\
\hline 3 & C & Cukup & $56-69$ \\
\hline 4 & D & Kurang & $41-55$ \\
\hline 5. & E & $\begin{array}{c}\text { Sangat } \\
\text { Kurang }\end{array}$ & $0-$ \\
\hline
\end{tabular}

HASIL PENELITIAN DAN PEMBAHASAN 
Observasi dilakukan ketika tindakan dilaksanakan pada setiap pertemuan. Berikut tabel hasil observasi kemandirian belajar siswa:

Tabel 2. Hasil Observasi Kemandirian Belajar

\begin{tabular}{|c|c|c|c|}
\hline \multicolumn{4}{|c|}{ Siswa } \\
\hline No & $\begin{array}{l}\text { Nama } \\
\text { Siswa }\end{array}$ & $\begin{array}{c}\text { Pertemuan } \\
\text { I }\end{array}$ & $\begin{array}{c}\text { Pertemuan } \\
\text { II } \\
\end{array}$ \\
\hline 1 & $\mathrm{X} 1$ & 50 & 75 \\
\hline 2 & $\mathrm{X} 2$ & 60 & 80 \\
\hline 3 & $\mathrm{X} 3$ & 45 & 60 \\
\hline 4 & $\mathrm{X} 4$ & 60 & 75 \\
\hline 5 & $\mathrm{X} 5$ & 65 & 80 \\
\hline 6 & X6 & 55 & 70 \\
\hline 7 & $\mathrm{X} 7$ & 50 & 65 \\
\hline 8 & $\mathrm{X} 8$ & 55 & 75 \\
\hline 9 & X9 & 60 & 80 \\
\hline 10 & $\mathrm{X} 10$ & 50 & 70 \\
\hline 11 & X11 & 45 & 55 \\
\hline 12 & X12 & 55 & 60 \\
\hline 13 & X13 & 50 & 85 \\
\hline 14 & X14 & 45 & 65 \\
\hline 15 & X15 & 60 & 80 \\
\hline 16 & X16 & 50 & 60 \\
\hline & & 855 & 1135 \\
\hline Rat & & 53,43 & 70,93 \\
\hline
\end{tabular}

Perhitungan tabel diatas, maka nilai ratarata siswa di hitung dengan Berdasarkan menggunakan rumus berikut ini :

a. Pertemuan I

$$
\mathrm{P}=\frac{f}{n} \times 100 \%
$$

$$
\begin{aligned}
& \mathrm{P}=\frac{855}{16} \times 100 \% \\
& \mathrm{P}=53,43 \%
\end{aligned}
$$

b. Pertemuan II

$$
\begin{aligned}
& \mathrm{P}=\frac{f}{n} x 100 \% \\
& \mathrm{P}=\frac{1135}{16} \times 100 \% \\
& \mathrm{P}=70,93 \%
\end{aligned}
$$

Berdasarkan pada tabel 4.5. Hasil observasi pada pertemuan pertama menunjukkan bahwa kemandirian belajar siswa termasuk pada kategori kurang, yaitu sebesar $53,43 \%$. Pada pertemuan kedua termasuk kategori baik yaitu sebesar 70,93\%.dapat dilihat pada diagram dibawah:

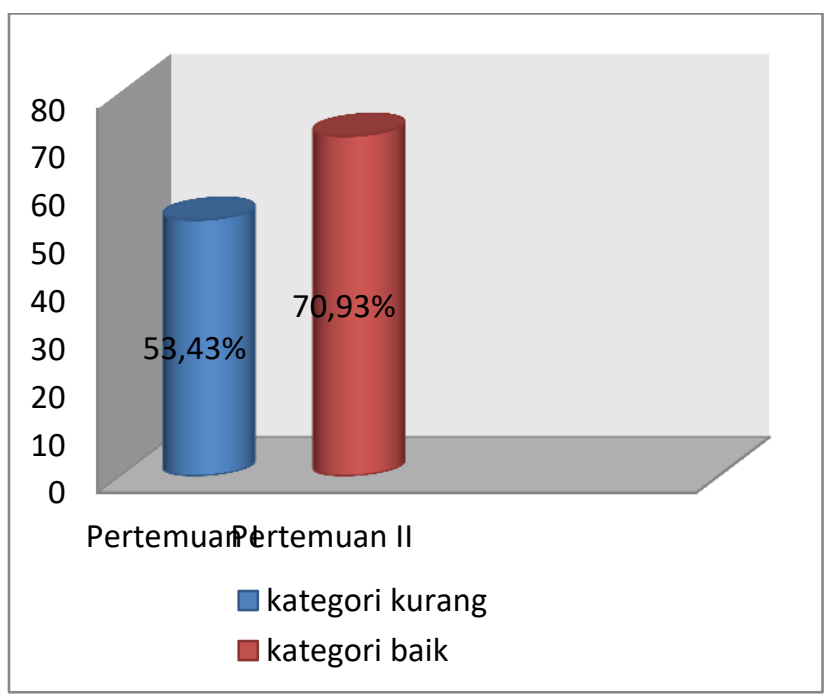

\section{Gambar 1. Diagram perbandingan peningkatan} hasil nilai Observasi kemandirian belajar siswa pertemuan I dan II

Dengan hasil tersebut terlihat peningkatan kemandirian siswa, yaitu $20 \%$ dari pada pertemuan I. Hal ini berarti Pembelajaran IPA dengan strategi pembelajaran Active 
Learning terlaksana sesuai tindakan yang direncanakan, baik pada pertemuan pertama maupun kedua. Guru juga telah memfasilitasi dan memotivasi siswa untuk meningkatkan kemandirian belajarnya.

Selain observasi, teknik pengumpulan data yang digunakan dalam penelitian ini adalah angket untuk mengukur kemandirian belajar siswa. Hasil angket kemandirian belajar siswa pada pertemuan peratama dan kedua dapat dilihat pada tabel berikut:

Tabel 3. Hasil Angket Kemandirian Belajar Siswa

\begin{tabular}{|c|c|c|c|}
\hline No & $\begin{array}{c}\text { Nama } \\
\text { Siswa }\end{array}$ & Pertemuan I & Pertemuan \\
II \\
\hline 1 & $\mathrm{X} 1$ & 40 & 75 \\
\hline 2 & $\mathrm{X} 2$ & 55 & 80 \\
\hline 3 & $\mathrm{X} 3$ & 45 & 65 \\
\hline 4 & $\mathrm{X} 4$ & 70 & 95 \\
\hline 5 & $\mathrm{X} 5$ & 60 & 90 \\
\hline 6 & $\mathrm{X} 6$ & 45 & 75 \\
\hline 7 & $\mathrm{X} 7$ & 80 & 95 \\
\hline 8 & $\mathrm{X} 8$ & 65 & 75 \\
\hline 9 & $\mathrm{X} 9$ & 75 & 80 \\
\hline 10 & $\mathrm{X} 10$ & 40 & 65 \\
\hline 11 & $\mathrm{X} 11$ & 55 & 80 \\
\hline 12 & $\mathrm{X} 12$ & 80 & 95 \\
\hline 13 & $\mathrm{X} 13$ & 45 & 70 \\
\hline 14 & $\mathrm{X} 14$ & 50 & $\mathbf{1 2 9 0}$ \\
\hline 15 & $\mathrm{X} 15$ & 60 & 90 \\
\hline 16 & $\mathrm{X} 16$ & 55 & $\mathbf{8 2}$ \\
\hline Jumlah & $\mathbf{9 2 0}$ & $\mathbf{5 7 , 5}$ & \\
\hline Rata rata & & 75 \\
\hline
\end{tabular}

Perhitungan tabel di atas, maka nilai rata-rata siswa di hitung dengan menggunakan rumus berikut ini :

a. Pertemuan I

$$
\begin{aligned}
& \mathrm{P}=\frac{f}{n} x 100 \% \\
& \mathrm{P}=\frac{920}{16} \times 100 \% \\
& \mathrm{P}=57,5 \%
\end{aligned}
$$

b. Pertemuan II

$$
\begin{aligned}
& \mathrm{P}=\frac{f}{n} x 100 \% \\
& \mathrm{P}=\frac{1290}{16} \times 100 \% \\
& \mathrm{P}=80,62 \%
\end{aligned}
$$

Berdasarkan perhitungan pada tabel di atas, Hasil angket pada pertemuan pertama menunjukkan bahwa siswa memiliki Kemandirian belajar pada katagori cukup sebesar 57,5\%. Pada pertemuan kadua termasuk katagori sangat baik yaitu sebesar $80,62 \%$. dapat dilihat pada gambar diagram dibawah ini:

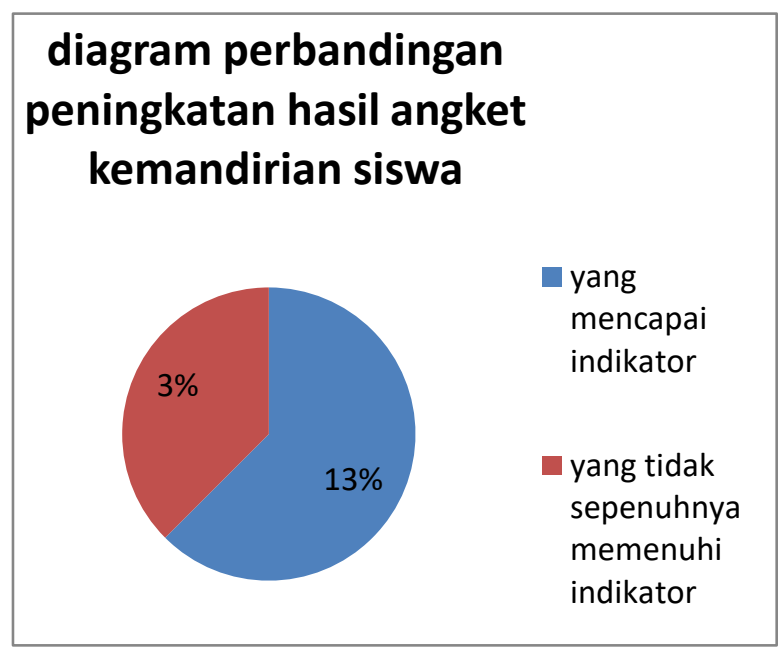


Gambar 2 Diagram perbandingan peningkatan hasil nilai angket siswa pertemuan I dan II

Dengan hasil tersebut terlihat peningkatan kemandirian siswa, yaitu 13 dari 16 siswa mampu mencapai indikator yang telah di tentukan, dan 3 siswa yang belum sepenuhnya mencapai indikator. Berdasarkan kesepakatan dengan guru kelas, indikator keberhasilan yang digunakan dalam penelitian ini yaitu rata-rata kemandirian belajar siswa berdasarkan hasil observasi dan angket masing-masing $\geq 75 \%$.

Data hasil belajar pre-test dan post-test siswa yang dikumpulkan menggunakan evaluasi dalam bentuk pilihan ganda sebanyak 10 soal.

\begin{tabular}{|l|l|c|c|c|}
\hline 11 & DW & 80 & 90 & Tuntas \\
\hline 12 & MH & 55 & 65 & $\begin{array}{c}\text { Tidak } \\
\text { Tuntas }\end{array}$ \\
\hline 13 & MN & 80 & 90 & Tuntas \\
\hline 14 & IB & 40 & 60 & $\begin{array}{c}\text { Tidak } \\
\text { Tuntas }\end{array}$ \\
\hline 15 & ASY & 50 & 75 & Tuntas \\
\hline 16 & MI & 70 & 85 & Tuntas \\
\hline \multicolumn{2}{|c|}{ Jumlah } & $\mathbf{1 0 9 0}$ & $\mathbf{1 2 9 5}$ & $\mathbf{8 0 , 9}$ \\
\hline \multicolumn{2}{|c|}{ Rata-rata } & $\mathbf{6 8 , 1}$ & $\mathbf{8 0}$ \\
\hline
\end{tabular}

perhitungan tabel diatas, maka nilai ratarata siswa di hitung dengan Berdasarkan menggunakan rumus berikut ini :

Nilai yang telah diperoleh siswa pada pre-test dan post-test dapat dilihat pada tabel 4.7 berikut:

Tabel 4. Hasil Pre-Test dan Post-Test

\begin{tabular}{|l|l|c|c|c|}
\hline \multirow{2}{*}{ No } & \multirow{2}{*}{$\begin{array}{c}\text { Nama } \\
\text { Siswa }\end{array}$} & $\begin{array}{c}\text { Pre- } \\
\text { test }\end{array}$ & $\begin{array}{c}\text { Post- } \\
\text { test }\end{array}$ & \\
\cline { 3 - 4 } 1 & TR & 80 & 90 & Tuntas \\
\hline 2 & RM & 70 & 80 & Tuntas \\
\hline 3 & PA & 70 & 85 & Tuntas \\
\hline 4 & NL & 65 & 80 & Tuntas \\
\hline 5 & AR & 60 & 75 & Tuntas \\
\hline 6 & DY & 90 & 100 & Tuntas \\
\hline 7 & AA & 45 & 55 & $\begin{array}{c}\text { Tidak } \\
\text { Tuntas }\end{array}$ \\
\hline 8 & AP & 90 & 100 & Tuntas \\
\hline 9 & NN & 85 & 95 & Tuntas \\
\hline 10 & RN & 60 & 70 & Tuntas \\
\hline
\end{tabular}

a. nilai rata-rata Pre-test

$$
\begin{aligned}
\dot{\bar{X}} & =\frac{\sum x}{N} \\
\dot{\bar{X}} & =\frac{1090}{16} \\
\dot{\bar{X}} & =68,1
\end{aligned}
$$

b. nilai rata-rata Post-Test

$$
\begin{gathered}
\dot{\bar{X}}=\frac{\sum x}{N} \\
\dot{\bar{X}}=\frac{1295}{16} \\
\dot{\bar{X}}=80,9
\end{gathered}
$$

Berdasarkan Tabel 4.8 menunjukkan bahwa nilai rata-rata pretest hasil belajar siswa sebelum dilaksanakan pembelajaran oleh peneliti adalah 68,1 berkategori cukup dan belum memenuhi indikator keberhasilan yang telah ditetapkan sehingga hasil pre-test dinyatakan belum tuntas,selanjutnya meningkat 
pada post-test dengan rata-rata 80,9 berkategori sangat baik dan sudah memenuhi indikator keberhasilan yang telah ditetapkan sehingga hasil post-test dinyatakan tuntas . Rekapitulasi nilai rata-rata pre-test dan post-test siswa kelas V SD Negeri Kandang yang telah diperoleh berkategori cukup dan tinggi dengan kenaikan rata-rata sebesar $70 \%$ dan yang tidak mencapai kategori cukup sebanyak 30\%, dapat dilihat pada gambar di bawah ini:

\section{Simpulan}

Berdasarkan hasil penelitian dan pembahasan maka diperoleh bahwa hasil belajar pada test awal (Pre-test) menunjukkan rata-rata hasil belajar siswa $68,1 \%$ dan pada test akhir (Post-test) diperoleh rata-rata hasil belajar siswa sebesar 79,3\%. Hal ini disimpulkan bahwa penerapan strategi pembelajaran Active Learning dalam pembelajaran IPA dapat meningkatkan hasil belajar siswa kelas V SD Kandang.

\section{DAFTAR PUSTAKA}

Agus N Cahyo, 2013. Panduan Aplikasi Teori-Teori Belajar Mengajar, Yogyakarta: Diva Press, 2013.

Ahman, dkk. 2006. Psikologi Pendidikan Teori dan Praktik. Terjemahan Mrianto Samosir. Jakarta : PT. Indeks.

Alben Ambarita, 2006. Manajemen Pembelajaran. Jakarta: Departemen Pendidikan Nasional

Arikunto, 2011. Prosedur Penelitian Suatu Pendekatan Praktik. Jakarta: Rineka Cipta.

Desmita, 2012. Psikologi Perkembangan Peserta Didik. Bandung: Rosda Karya

Hamzah B. Uno, 2010. Teori motivasi dan pengukurannya. Jakarta: PT Bumi. Aksara

Haris Mudjiman. 2008. Belajar Mandiri (Self Motivated Learning). Surakarta: UNS Press.

Haris Mujiman. 2011. Manajemen Pelatihan Berbasis Belajar Mandiri. Yogyakarta: Pustaka Pelajar.

Hasan Basri, 2006. Penilaian Hasil Proses Belajar Mengajar. Bandung: PT. Remaja Rosdikarya. Imam Musbikin, 2006. Mendidik Anak Kreatif Ala Eistein. Yogyakarta: Pustaka Pelajar.

Mohammad Asrori, 2009. Kurikulum dan Pembelajaran. Jakarta: PT Bumi Aksara.

Nana Sudjadna. 2005. Penilaian Hasil Proses Belajar Mengajar. Bandung: Remaja Rosdakarya.

Pusat Kurikulum, 2010. Evaluasi Pembelajaran: Prinsip, Teknik, Prosedur. Bandung: PT Remaja Rosdakarya. 